\title{
The Effects of Western Technology on African Cultural Values
}

\author{
Abanyam, Noah Lumun \\ Department of Sociology University of Mkar, Mkar, Benue State-Nigeria
}

\begin{abstract}
Africa depends on western technology without developing their own indigenous knowledge. This dependency status has enormous challenges since some of these western technologies are not congenial with African environment. This study was designed to ascertain the Effects of Western technology on African cultural values. Postmodernism was employed as a theoretical model in analyzing the study. The findings showed that western technology exposed young people to adult issues, hideous violence, indecent dressing, immorality and build negative attitude that are contrary to African cultural values. It is recommended that Government should regulate the influx of western technology and promote the indigenous technology in order to protect African society from the adverse effects of the western technology.

Key words: technology, Africa, cultural values, postmodernism, effect.
\end{abstract}

\section{Introduction}

Technology is a "cultural information about how to use the material resources of the environment to satisfy human needs and desires" (Nolan and Lenski, 2006:37). Africa is witnessing the effects of western technology with its occupying blessings and curses. The reality is that Africa lags behind in accelerating appropriate indigenous scientific knowledge to solve their problems (needs). Therefore, they depend on western technology. These dependency syndromes have an enormous challenge on African cultural values. Some of these western technologies (devices) are not congenial to African context and have rather helped to erode (reduce) African cultural values to zero mark. Ahule (2010:6) captures this picture more vividly thus:

Africa and indeed Nigerian value system have metamorphosed from its collective orientation to take on a western form. Rather than taking on African form, values congruent with western society have come to dominate the African way of life, and rather than solidly the African, it degenerate him.

In the traditional African society today, children are losing the ability to play properly because of the influx of western technological devices like toys and computer games. In many higher institutions across Africa, indecent dressing has become the emblem of modernity. African society is now grappling with many behavioral problems of dishonesty, drug abuse, assault, insult, gansterism, violent demonstrations, vandalism, examination malpractices, robbery and secret cult activities (Nnachi, 2003). It is in view of these prevailing situations that this study is designed to investigate the effects of western technology on African cultural values.

\section{Theoretical Framework}

Postmodern society theory will be considered expedient in analyzing this study.

\section{Postmodern social Theory}

Postmodern theorist believes that the society has entered a new era, and that all modern ideas in society are outdated. Postmodern society is a technologically sophisticated society that is preoccupied with consumer goods and media images (Brannigan, 1992). Such societies emphasizes on new cultural products and a new approach about the social world. Postmodern societies consume goods and information on a mass scale. Such societies ushered in something new different in modern years that can no longer be tenable (Ritzer, 2008). According to Schaefer (2008:125):

Postmodern theorists take a global perspective, noting the ways that culture crosses national boundaries. For example, residents of the United states may listen to reggae music from Jamaica, eat Sushi and other Japanese foods, and wear clogs from Sweden. And the online social networks know no national boundaries. The emphasis of postmodern theorists is on observing and describing newly emerging cultural forms and patterns of social interaction.

In a postmodern society, people consume goods, information, and media images en masse. Postmodern society is an era in which anything goes; all styles and fashion are permissible (Haralabos and Holborn, 2008). Proponents of this perspective are Jean Baudillared, Jean Francois Lyotard, Bogard, Binkley, etc.

In relation to the effects of western technology on African cultural values, postmodern social theorist seeks to explain that African society (society world over) have entered an era where information technology and social life are consumed globally. Human cultural values (ideas) are all integrated across the globe. One can therefore 
exhibit certain behaviours based on the information available globally (whether in Europe, Asia, Africa, United State of America, etc). The basic assumption here is the control over knowledge as a major source of power. In this connection, western societies because of their technological superiority has control over knowledge and information globally which they project their cultural values, most of these diffused western cultural values are contrary to African cultural values and are having effects on Africa.

\section{Effect of Western Technology on African Cultural Values}

Africa has a relatively rich body of indigenous knowledge and related technologies which has being for thousand years to solve their problem. Despite their contributions, such indigenous knowledge and technology are not used. Rather they rely on western technology to accelerate their development. Abanyam (2012: 105) in Akpan explain that:

Before the advent of modern science and its application technology, the Africans had known how to brew beer, distill local gin, preserve corpses, weave cloths, make pots of different shapes, colours and sizes, build houses, make astronomical observations, heal diseases of different types through herbs and roots, rear cattle and do many other things. But what has happened to these indigenous sciences today? Some of them have lost because of the influence of western scientific paradigm.

The major problem here is that not all western technologies are congenial with African worldview. Some of these western technologies have rather helped to reduce African cultural values. The youths appeared to be the most venerable group affected by the influx of these western technologies. Western culture transmitted through technological devices (pornographic movies or materials) "exposed young people to adult issues at impersonate age" (Denga 1983). African societies are now facing many problems, among which is sex abuse. These seem to be having effects on African society. In the traditional African context, girls avoided pre-marital sexual experience for fear of social punishments usually meted out to girls who lost their virginity before marriage. Today's situation shows a sharp contrast to the African cultural values.

Many western electronic games, movies literature and bad models promote immorality, profanity, and violence. Some of them (games) glorify occult practices and features gang wars, drug use, explicit sexual content, foul language and intense violence. Studies repeatedly show that watching violent entertainment increases aggression in those who view it ( Denga, 1983, Nnachi, 2003). Bad models propelled our youth in exhibiting and committing crime in the society. Aggression and violence are learned by watching foreign movies. When the youths witnessed violent display in these movies, they tend to conclude that violence is a way of life. Gangsterism and modern cultism in many higher institutions in Africa may be an extreme of foreign technology. Today, African youths smoke marijuana and other dangerous substances, they maimed, loot, rape, shop lift, hired as thugs, steal and hawk drugs. These compelled them to engage in crime which impact on the society is so grievous. Awake magazine (2008: 18) clearly explains:

Role - playing games have become hugely popular among children. In these, participants create online characters-whether human, animals, or a blend or both that inhabit a computer-generated world populated by thousands of other players. This online world contains shops, cars, homes, dance, clubs, brothels - in essence; it is replica of the real world. The players in these games are able to instant massage one another as their computer generated character, called avatars or interact. Here sex is commonplace, as is prostitution. Just by pressing a few buttons, the players can make their avatars engage in sex acts while the real -world participants talk about sex via instant massaging. Inadtion, those world are full of virtual crimes, mafia men, pimps, extortionist, counter feiters and assassins. Some features rape fantasies, or people who indulge in sex acts using avatars that resemble children.

Exposure to such graphic sex and hideous violence can damage African cultural values. Jean Jacques Rousseau realized this problem and warned that a child should be protected from the corruption of civilization. To him, nature is the best, to learn from it is to avoid the unhealthy traits associated with modern civilization, and he argued further that children (Emile) should be saved from any contact with modern civilization.

Another adverse effect of western technology on African cultural values is on indecent dressing. Clothing is one of the basic needs of man and there is absolutely no spheres of human activity in which African values and life styles can be clearly reflected than the cloths we wear. Clothing played a cardinal role in stimulating or diminishing sexual urge symbolic to the moral standard of a given culture (Turrayo, 2008). In African society, there were certain accepted standard of dress that were are considered appropriate and inappropriate but with the influx of foreign movies (western technology) indecent clothing like mini skirts and skinned tight cloths that exposes breast, chest, belly upper arms, armpits and buttons are increasingly common among little ones in Africa and are seem as modern fashion. This is contrary to African cultural values.

Today in Africa, most of our girls are almost naked on the street. The consequences of this acts are enormous, we have many rape cases everywhere. Indecent dressing has been blamed for everything AIDs, sexual harassment, a lot abortion, death, etc. the desire to pursue foreign fashions (clothing styles, make up, bangles, and jewelries) excessively advertized by foreign media forced many African children into prostitution 
because of material things. Some become drug carriers. This made them to lose their family and religious values as well as African cultural values in general. We now have culture that is very alien to Africa thought. Exposure of the body suggests careless life style and is contrary to the values, ideas and norm of African society and it often attracts undue attention from male and female alike.

In many African institutions of higher learning, our girls deliberately dressed indecently or expose their body parts and made unnecessary visits to lecturer's offices and make suggestive or provocative gestures. These made some male lecturers to demand sex from female students in exchange for carpet grades. This many have a very serious implication on the standard of education in Africa.

Western technology also helped in shaping our children's attitudes and perceptions. Computer games (electronic games) have shaped children's thinking. Many children in Africa do no have a correct understanding of what death really means. They think that once a person dies, that person can be restored to life. This perception may have been derived from computer games in which, even when a hero dies, all what one has to do is to press the reset button to start it all over again from the scratch. This thinking also may have a disastrous effect on African society.

Finally, western technology has adverse health implications that are contrary to African cultural values. Western agricultural chemicals such as pesticides imported in to Africa are use in poisoning bees and fishes. This has serious effect on African health. The attendant consequences of these behavioural pattern are gravious and disturbing to African health care planners ( Etobe, 2002).

\section{Conclusion and recommendations}

It is obvious that western technologies are having disastrous effects on African cultural values. The inability of Africa to develop their indigenous scientific knowledge exposes them to many challenges. This study has identified (Exposed) a highly reliable body of evidence on the effects associated with western technology on African cultural values. Such as exposure of young people to adult issues, sexual abuse, hideous violence, indecent dressing, immorality and building of negative attitude among the youths that are not in line with African cultural values. The study is a revelation to Africans to be worry of the kind of technology they import in to this continent. There is therefore urgent need to develop our local indigenous knowledge that can solve African problems.

Based on the foregoing discussion, the following recommendations are made:

Government should regulate the influx of western technology (foreign movies, computer games, pornography, etc) to protect African society from the adverse effects of western technology.

Government, curriculum designers and educationists should implement a comprehensive moral education curriculum at primary, secondary and tertiary institutions. This will go along way to inculcate African cultural values as well as discourage western cultural values that are not in consonants with the African way of life.

Parents, counselors, social workers, policy makers and religious leaders should provide the young ones with adequate relevant information regarding the hazardous effect of western technology.

African parents should be fully awake to their responsibility and teach certain aspect of African moral values to their children so that their children will be discourage to dress indecently

Relatedly, there is need for mass media to keep enlightening the parents on the importance of home discipline on the life of their children. This is necessary to eradicate or at least alleviate the effect of western technology on the African cultural values.

African government should encourage the development of indigenous technology that is consistent with African cultural values. In this way, the continent can move away from the adverse effects of western technology.

\section{References}

[1] Abanyam, N. L, (2012) "The Realistic of Technological Transfer in Africa and the Challenges for Development" Published in Africa Journal of Economy and Society, Vol 11, No. 2. Makurdi: Aboki Publishers.

[2] Ahule, B. G. (2012). "The Crisis of Moral Values and the Dilemma of Development" Published in Benue Journal of Sociology, Vol. 3. No. 1 Makurdi: Selters Academic Press.

[3] Awake Magazine (January, 2008) "Should I Play Electronic Games?

[4] Brannigan, A. (1992) "Postmodernism" Pp. 1522-1525 in Encyclopedia of Sociology, Vol. 3, Edited by Edgar .F. and Marie .L. New York: Macmillan.

[5] Denga, D. I, (1983) “De-Juvenilizing Secondary Schools in Nigeria through Behavioural Counseling Techniques” the Counselor Journal of the Counseling Association of Nigeria, 5 (1) pp 29.

[6] Etobe, I. E, (2002). Sociology of Health and Rehabilitation. Calabar: Baye Communications Ltd.

[7] Haralambos, M and Holborn, M ( 2008). Themes and Perspectives. Oxford: Oxford University Press.

[8] Nnachi, R. O. (2003) The Behavioural Problems Among Nigerian Children. Awka: the Nigerian Society for Educational Psycholoigist ( NISEP).

[9] Nolan, P and Lenski, G. (2006) Human Societies: An Introduction to Macrosociology. Boulder: Co Paradigm.

[10] Ritzer, G. (2008) Sociological Theory. New York: McGraw-Hill.

[11] Schaefer, R.J. (2008) Sociology. New York: McGraw-Hill Companies, Inc.

[12] Tunrrayo, A. T (2008) "Opinion of Parents in Abraka, Delta State Nigeria ion Dress Code and its Effect on Family Survival" Published in Pakistan Journal of Social Sciences 5/2/: 147-151. 